\title{
Discussion on Implementation of the Excellent Engineers Training Program of Mechanical Design Manufacturing and Automation Major
}

\author{
Han Bin, Liu Yonghong, Zhang Yanting \\ College of Mechanical and Electronic Engineering \\ China University of Petroleum \\ Qingdao, Shandong, 266580, China \\ hbzhjh@upc.edu.cn
}

\begin{abstract}
According to the direction of "Excellent Engineers Education and Training Program”, the article makes a brief introduction of mechanical design manufacturing and automation major, considering the current condition of this major of China University of Petroleum (East China). The article also detailedly illustrates the implementation objectives and working thoughts of the excellent engineers training mainly from two aspects, which are the training mode construction and education environment construction.
\end{abstract}

Keywords-mechanical design manufacturing and automation major; excellent engineer; talent training

\section{INTRODUCTION}

The "Excellent Engineers Education and Training Program” ("Excellence Program” for short), was officially launched by Ministry of Education, together with some related departments and institutions of industries in Tianjin on the day 23rd June, 2010. The primary objective of the "Excellence Program" is to cultivate a number of highly qualified engineering talents who have strong ability of innovation and can meet the social demand. The program serves for the national strategy of approaching new industrialization path, building innovation-oriented country and the Strategy of Strengthening Country on Talent [1]. The program plays a leading role in two aspects, which are promoting the talents cultivation of tertiary education based on the demand of society and comprehensively improving the quality of engineer education and training [2].

With the guidance of Equipment Manufacturing Industry Restructuring and Revitalization Plan, our country is developing its capacity of independent innovation. However, compared with industrialized countries, our country still lacks of engineering technology talents engaged in high-tech research, new technology application, intersectant technologies innovation, and developing new techniques and theories. Mechanical equipment manufacturing industry is in badly need of excellent engineers with leading capacity [3]. Mechanical design manufacturing and automation major from college of mechanical and electronic engineering of UPC is one of the second group to be authorized to practice "Excellent engineers" education and training. As the major involves a broad scope of knowledge and abundant contents, it requires intellectuals to have strong abilities of engineering practice. However, the traditional talent training mode lacks the cultivation of students' engineering practice ability and innovative thoughts. As a result, graduates are often short in knowledge, manipulative ability, and comprehensive engineering quality, which also make it difficult to quickly adapt to new working environment. For the purpose of improving talent training quality, we should focus on "Excellence Program" and the objective of revitalizing oil field equipment manufacturing industry of China. In order to serve petroleum and petrochemical industries and economic construction of Shandong province better, we should also foster a body of highly skilled talents with good mastery of advanced manufacturing technology.

\section{BRIEF INTRODUCTION OF MECHANICAL DESIGN MANUFACTURING AND AUTOMATION MAJOR}

The predecessor of mechanical design manufacturing and automation major (mechanical automation for short) is called "oil field machinery", which was established in department of petroleum of Qinghua University in 1952. The name was officially decided in 1953, when Beijing Institutes of Petroleum was founded based on the department of petroleum. In 1983, the major was altered to "mining mechanics", and "mechanical design and manufacturing" in 1993. Finally in 1999, the major was merged into "mechanical manufacturing process and equipment", turning into the current mechanical automation major. On August 2011, the Ministry of Education officially approved the affiliation of mechanical automation major of China University of Petroleum (East China) to the "Excellence Program”. An undergraduate experimental class of 35students had been set up since 2012. Training of experimental class focuses on the balance of two aspects, which are mechanical design and mechanical manufacturing. Featuring oil field machinery, the practical teaching was continuous in 4 years, so as to lay a good foundation for training application-oriented engineers.

\section{CONSTRUCTION OF TRAINING MODE FOR EXCELLENT ENGINEERS}

\section{A. Training objectives}

Mechanical automation major aims to foster international engineering talents who can adapt to the economic globalization and socialism modernization construction of our country. Those talents should have all-round development in morality, intelligence and physical education and a good mastery of basic theories, practical techniques, foreign languages and computer application. They should not 
only get familiar with the systematic theory of mechanical and electrical engineering, but also have broad horizon, innovative thinking, as well as the ability to design mechanical and electrical products. Featuring oil and gas field equipment, graduates from this major would be competent in the following fields, such as mechanical and electrical system design, mechanical manufacturing, engineering design, constructing operation, technological development, production technology administration, and scientific research in companies related to petroleum, petrochemistry, mechanics, energy, etc.

\section{B. Working plan}

As a pilot major, mechanical automation utilizes small class system, considering that a relatively small number of students would make them easier to participate in the research of real engineering projects. After a certain period, the training mode of "Excellence Program" would spread within the entire major.

All of the 35 students from the experimental class were first-year students of mechanical automation major in 2012 spring semester. The class was set up by voluntary application and competitive selection. As some of the students were selected from those who transferred to this major, the multiple sources of students would make the process and results more comparable. During the experimental training process, students were allowed to choose their directions according to their own interest. For those short in manipulative abilities or have difficulties, they can go back to normal classes for futher study. The whole training process will be practicing dynamic training mechanism and free option of direction mechanism.

\section{Training mode}

The training mode of excellence program will focus on "engineering", and endeavor to enhance students' engineering thinking, engineering qualities and engineering practical abilities. The training mode of undergraduates in engineering is adopting " $3+1$ " 4-year undergraduate training method, including a 3-year study on campus, as well as a 1 -year in sum study and practice in companies. Students of the experimental class can be recommended for postgraduate study.

The training will emphasize on the cultivation of practical abilities, combing theoretical knowledge with real engineering projects. The whole training process will include production, teaching and scientific research. By teaching, practicing, studying and applying at one time, the training process gets closer to society, market and production. Only with the combination of course learning and engineering practice, can we practice the school-company combining education.

Furthermore, the university is seeking for cooperation with domestic and overseas government, enterprises, and education and research institutions, for the purpose of sending more students for short-term study in well-known institutions. In particular, more and more teachers and students are sent to famous enterprises for internship and practice. Some prestigious experts and scholars are invited to participate in the construction of courses and practical teaching. Besides, the university is culturing internationalized teachers, absorbing advanced international teaching content, and building international campus environment, in order to effectively implement the internationalization strategy.

\section{Major training plan}

On the basis of studying math, physics, English, computer and engineering drafting, students of this major also mainly study theoretical courses such as mechanical design, mechanical manufacturing, petroleum engineering and equipment, theoretical mechanics, material mechanics, controlling engineering, lector mechanical information detection and processing. At the meantime, they need to accept practice trainings like practice in metalworking, mechanical manufacturing, and oil drill and exploit equipment comprehensive training, as well as computer application and engineering design methods training. This major is not only a universal mechanical engineering subject, but also a supporting subject of petroleum mechanics industry. Training of experimental students focuses on the balanced development of both mechanical design and mechanical manufacturing. Featuring petroleum mechanics, practical education is continuous in 4 years, laying sound foundation for training application-oriented engineers.

\section{ENVIRONMENTAL CONSTRUCTION FOR EXCELLENT 年}

\section{A. Teaching staff construction}

1) Strengthen the practical and scientific research capacity of teachers

A high level teaching staff is the primary premise of practicing "Excellence Program". The department of mechanical automation, which is the major training organization, consists of 33 teachers, including 11 professors and 10 associate professors, 18 of them hold doctorate degree, and 2 are members of National Millions of Talents Project. The department also possesses a First Level Discipline authorized to offer doctorate degree of mechanical engineering. For the last 5 years, this department has been funded by more than 60 programs including the national 973 , the 863, State Research Projects, National Nature Science foundation of China (NSFC), National oil and gas major projects and projects of petroChina, Sinopec, CNOOC. It is an important component of The National "985" Advantage Discipline Innovation Platform, and has the capacity to launch basic front edge projects and national key projects.

As young teachers generally lack the understanding of engineering practice and the quality of engineering, they tend to separate engineering practice from theoretical teaching. Therefore, during the first several years, the main work of young teachers is to attend class and assist teaching. With the guidance of experienced professors and experts, young teachers should positively participate in the betterment of engineering practice courses. Eventually by sending teachers to companies for engineering practice and research group by group at different time, their capacity and quality of engineering will be improved immensely. 
Teachers' capacity of research should be Further intensified. By researching works, teachers can not only improve their own professional qualities, but also put their research experience into their teaching, which is a win-win strategy. By spirit of teamwork and tradition of passing on, the scientific research work of all teachers will achieve a higher level, providing a better platform for students to participate in scientific research.

2) Fully develop teacher resources from enterprises

Experts are hired from enterprises to teach some courses. The qualification and credentials for hiring teacher from university or enterprises must be clarified. Double tutor system is adopted during the practical teaching and graduation design, which means besides tutor from university, an expert from enterprise must be hired to direct students at the same time. Full or part time teachers with working experience in companies will be firstly considered.

\section{B. Construction of teaching conditions}

College of Mechanical and electronic Engineering sets up a teaching and experiment center for teaching and experimental work of the entire college and to ensure the experimental requirements of "Excellence Program" by using college's resources effectively. So far, the mechanical design manufacturing and automation major already has a complete teaching laboratory and has initially set up a hierarchical, modular and open experimental teaching mode, as well as a special mechanical and electrical innovation laboratory which mainly focuses on training students' innovative ability. According to the plans, for the next three years, mechanical design manufacturing and automation will continue to supplement and improve the experimental conditions by using the "major comprehensive reform unit" project and the "basic construction of teaching" project. Relying on the already signed extramural enterprise practice base, the college establishes a school-company joint training, and signs joint personnel training agreement with enterprise to attract technical experts from enterprises to be teachers. Additionally, the college can take advantage of the equipment, environment and advanced technical information of enterprises as practical teaching resources.

Practice curriculum and practical sections of related curriculums required by "Excellence Program" consist of two parts, which are internal practice on campus and external practice in companies. For practical courses on campus, practice locations and the necessary equipment must be in place, at the same time the necessary financial support for opening laboratory for students' innovative experiment must be provided. Since the foundation, China University of Petroleum (East China) had been maintaining close contacts with the enterprises and research units. So far, the internship bases that have already finished include Shengli oilfield branch of China petroleum and chemical Co. LTD., Weichai Power Co. LTD., Shengli Oil Field Highland Petroleum Equipment Co. Ltd., Shengli Oilfield Freet Petroleum Steel Pipe Co. Ltd., Shandong Kerui Petroleum Equipment Company LTD. and the general factory of mechanical and electrical equipment of China University of Petroleum.

\section{Teaching construction and teaching reform}

Considering that the present professional courses start late, in the excellent engineers training program, the basic professional courses are brought forward to the second grade, and professional introduction, freshman seminars and other professional related courses are set up in the first grade. All the above is to ensure that students get "early contact, early awareness and early training" of their major, which would help them understand the role and significance of each basic course in the future professional learning to enhance their learning enthusiasm and initiative. Referring to the training mode, we will transform the learning pattern of students from passive accepting to positive learning.

Considering that the present professional elective courses are too concentrated, the professional elective courses are grouped, classified, optimized and simplified by dividing the courses into professional foundation course and professional orientation course. The professional foundation courses are brought forward to the third and fourth semester, while the professional orientation courses are centralized in the fifth to seventh semester.

During the process of school-company joint training, the professional teachers and enterprise engineers who joined the program are to develop a flexible, highly operational plan, by which the teachers can take fully advantage of the local conditions, and teach students in accordance with their aptitudes. In this way, practice teaching can alter from the virtual teaching on campus to the actual production of enterprises, and from the theoretical discussion to on-site operation.

Vocational education is brought into the undergraduate teaching. In order to strengthen the undergraduate experience in engineering practice, the United States, France and Germany regard the vocational education as an important element of the undergraduate education [4]. Therefore, mechanical design manufacturing and automation major also establishes additional AutoCAD certification, Solid Works Certification, Pro/ENGINEER professional certification, UG certification and other contents for software engineers' vocational training. What companies need are talents who can work independently, so all kinds of software engineer training are the follow-up education for students to transform from "generalist" to "professional", which is a powerful guarantee for excellent engineer training. College graduates who have accepted vocational qualification training can get into the independent working state more quickly, and are well received by the enterprises.

What's more, the program will pay attention to students' individual needs, regard the students as the main body of teaching and learning, guide students to learn with questioning thoughts, master the method of research learning and strengthen students' engineering and innovation ability.

\section{Quality control and guarantee}

The quality monitoring and guarantee system of excellent engineers training program mainly includes the following aspects: 
1) Completion of student selection and teaching and other related systems [5]

Firstly, increase the propaganda strength of excellence engineer training program within the university; enable students to correctly understand the training objectives of the excellence program; encourage and guide students to take the initiative to get to know the professional characteristics, employment orientation, work content and other aspects of mechanical design manufacturing and automation; establish a set of scientific and highly operational student selection system.

Secondly, about the " $3+1$ " mode of outstanding engineers training, the department should play a leading role in teaching resource allocation, student status management and other aspects. Confronted with some conventional and special conditions, the department should take corresponding measures which are comprehensive and reliable, to truly guarantee the personnel training.

2) Establish a perfect teacher training and selection system

First of all, introduce and develop a number of practical experienced "Double Type" teachers. Encourage school teachers to go to the communities and participate in social practice. Through postdoctoral studying in companies, tempering training, scientific research cooperation and other forms, young teachers' engineering practice qualities can be cultivated. By further improving the teachers' titles of appointment, evaluation and training system, effective incentive mechanism can be formed, in order to promote the construction of full-time teaching staff.

Secondly, employ experienced engineers from the enterprise as the on-site tutors of the program. To achieve this goal, the college must have flexible insight into policies according to the reality. For instance, some experienced engineers in enterprises can't be hired by colleges or universities as instructors because they don't have the academic qualifications or titles due to their educational background or establishment, however, this group of engineers are just the best partners we need to make up for school education.

\section{3) Develop a comprehensive evaluation system}

Evaluation of practice teaching has always been a bottleneck problem, because there is a large difference between practice teaching mode and theoretical teaching in class, the main reason is that teaching environment is usually uncertain and the quantitative standard evaluating students' individual work is difficult to set up, etc. This makes the evaluation of practice teaching not so objective, and to some extent also influences the students' enthusiasm and initiative in practical learning. According to the conditions above, a set of highly operational and more objective evaluation system of practice teaching has been formulated, which specifically includes practice teaching summary reply and professional qualification certification.

Practice teaching summary reply is set up for the practice teaching section which has relatively concentrated time and content. Students are organized by teachers from school to attend reply as individuals, and instructors are invited from practice bases and enterprises, so that they can not only master students' practical learning more objectively, but also guide students to do deeper thinking. After completing all the practice teaching section, professional qualification authentication can be carried out according to their professional condition, which also helps to comprehensively assess students' practical learning outcome.

\section{CONCLUSION}

The Excellent Engineers Training Program follows the trend of economic globalization, but talent training is a long-term systematic project. By the opportunity of "Excellence Program", College of Mechanical and electrical Engineering of China University of Petroleum (East China) has built up a perfect excellent engineers training mode and created a good and effective engineering education environment. The program aims to improve the quality of talent training, and culture the entrepreneurship, research-oriented top talents and industry leaders who look to the future world. What's more, through the research of excellent engineers training, we hope to find out a path of the excellent engineers training that is full of our own characteristics, and also find out new ideas for college talent cultivation in China.

\section{ACKNOWLEDGMENT}

This research was partially supported by the Teaching Reform Key Projects of Shandong Province (No. 2012018) and the Training Model Reform Pilot Project of China University of Petroleum (No. MS-E201102).

\section{REFERENCES}

[1] Ke Gong. Thinking and Exploration of the cultivation of excellent engineers. China University Teaching, 2010, (8): 4-5.

[2] Anfu Zhang, Xingfu Liu. Reflection on the Implementation of "A plan for Educating and Training Out-standing Engineers”. Research in Higher Education of Engineering, 2010, (4): 58-59.

[3] Yong Wang, Jianfeng Li. Discuss to Bring up Excellent Engineer of Mechanical Specialty. Modern Manufacturing Technology and Equipment, 2010, (6): 69-70.

[4] Zhenkang Peng. Exploration and Practice of Entrepreneurship Education at home and abroad. Industrial \& Science Tribune, 2011, 10(2): 123-124.

[5] Bin Han, Yonghong Liu. Thinking of excellent engineer training program and teaching mode. China Electric Power Education, 2012, (29): 19-20. 